UDC $72+338$

\title{
Publication of Technical Documents Required for State Construction Order
}

\author{
Igor N. Polovtsev
}

Saint-Petersburg State University, Russia

7/9 Universitetskaya emb., Saint-Petersburg, 199034, Russia

Deputy Head of Building \& Reconstruction Division

E-mail: i.polovtsev@spbu.ru

\begin{abstract}
The article deals with the scope of technical documents required to be published while placing state and municipal construction orders. The author comes to a conclusion that publishing of the technical documents promotes construction competition. Moreover, publication of documents results in increasing of both design engineers' responsibility for the quality of design works and the customers for acceptance and estimation of projects developed.
\end{abstract}

Keywords: in a row on construction; restoration; state order; design documentation; construction project; competition.

Introduction. Construction works are generally regulated by Articles 740-757 (clause 3 "The Building Contract" of section 37 "Contract of Hiring Work"), part two of the Russian Federation Civil Code [1].

In particular, under the building contract the contractor shall undertake in the period stipulated by the contract to build by the assignment of the customer a project or to perform other construction works, whereas the customer shall undertake to create for the contractor requisite conditions for the performance of the works, to accept their result and pay the specified price. The building contract shall be concluded to build or reconstruct an enterprise, building (including a dwelling house) or structure, to erect any other project, and also to perform assembly, start-up and other works indissolubly related to the project concerned. The rules for the building contract shall be also applied to the works involved in the major repairs of buildings, unless otherwise stipulated by the contract.

In cases where construction works are carried out for state or municipal needs a relevant state or a municipal contract shall be concluded with the contractor. Under this contract the contractor shall undertake to perform building, design and other works related to construction and repair of production and non-production facilities, and to transfer them to the state or the municipal customer, whereas the state or the municipal customer shall undertake to accept the performed works and pay or cause them to be paid. The contract should contain provisions on the scope and cost of the work to be done, starting and completion dates, amount and procedure for financing and payment for works, as well as on the methods to provide for ensuring performance of the parties' obligations.

Any matters beyond the scope of the Civil Code shall be regulated by the law on contracts of hiring work for meeting state or municipal needs [1]. Such law is currently considered to be Federal Law "On placement of orders to supply goods, carry out works and render services for meeting state and municipal needs" [2].

To enter into contracts for construction and assembly works the Federal Law "On placement of orders to supply goods, carry out works and render services for meeting state and municipal needs" provides for a public auction required to be held in the electronic form. In this case the sole estimation criterion shall be the contract price offered by a participant of the order placement.

Tendering procedures involving contractor selection criteria are permitted to perform heritage buildings restoration. 10\% change of the price and of the list of works performed is admissible for this type of works.

It is necessary to admit that the Federal Law "On placement of orders to supply goods, carry out works and render services for meeting state and municipal needs" can hardly be applied to bidding in the field of construction and assembly works. It is primarily related to impossibility to select a proper contractor relying only upon the price offered, as construction is a technically complicated process. It is mentioned by a number of experts in this field [3, 4]. The requirement 
that a placement participant must have a permit of a self-regulating organization (which has replaced construction industry licensing) does not so far provide quality in work performance either.

Some hopes are set on the transfer to a Federal contract system, though its provisions are still ambiguous, that is why it is not clear how this offered form of state order placement can be applied to construction and assembly works.

At the same time it should be noted that the existing federal legislation concerning placement of orders facilitates the competition and provides a greater number of contractors with an opportunity to take part in such procedures. Adequate estimation by the contractor of its capability to fulfill an order is an essential component of public bidding.

No possibility to change the state contract terms after the bidding process is finished binds the parties to specify all terms at once. In this case both the customer and the executor (contractor, supplier) should expressly understand the tendering (auction) documents. This is possible only in case of placement of complete and unbiased information on works (services) ordered. Estimate publishing only when placing an order does not provide an opportunity to make a correct valuation of the entire work complex. To make a correct estimation it is required either to visit the site or to study the technical documents.

Article 743 of the Civil Code [1] determines that the contractor shall be obliged to carry on construction and the related works in accordance with the technical documents determining the scope and content of the works and other requirements made for them and with the estimate fixing the price of the works. It expressly implies that the estimate is not deemed to be a substitution for the technical documentation. The following is to be recognized as the technical documents referred to in this Article of the Civil Code:

in case of construction and assembly works - design documentation to be developed in accordance with the Regulation on composition of design documentation sections and the requirements to their content, approved by the Decree of the Russian Federation Government "On the composition of sections of design documentation and requirements to the content thereof" [5, 6];

in case of repair and restoration works - science and design documentation worked out according to the restoration rules and regulations "Recommendations on carrying out scientific and research, survey, design and production works aimed at preservation of the cultural heritage objects (historical and cultural monuments) of the peoples of the Russian Federation. SRP-2007 (4th version)" $[7,8]$.

Complete characteristics of an object of construction are given in design and estimate documentation. The scope of design and estimate documentation has been determined by the Decree of the Russian Federation Government "On the composition of sections of design documentation and requirements to the content thereof" [5].

As follows from a direct reference in the text of the Regulations, they establish the composition of sections of design documentation and the requirements to the content thereof in the course of preparation of design documentation for separate stages of construction, restoration and major repairs of major construction objects.

This legal act applies both to new construction and major repairs. And clause 7 of the Regulations establish that if financing is ensured, in full or in part, from corresponding budgets, development of the following sections shall be obligatory:

- "Data on MEP equipment, engineering and technical services, list of engineering measures, content of process solutions" (consisting of the following sub-clauses: "Power supply system", "Water supply system", "Water disposal system", "Heating, ventilation and air conditioning. Heat supply networks", "Communication networks", "Gas supply system", "Process solutions");

- "Construction organization plan";

- "Fire safety measures";

- "Estimate for construction of major construction objects".

Measures on ensuring compliance with the energy efficiency requirements and with those of equipment of buildings, premises and structures with used energy resources metering devices.

Development of other sections of design documentation has been left by legislature for the customer's discretion. 
Clause 3 of the "Regulations on the composition of sections of design documentation and requirements to the content thereof" states that design documentation consists of a text and a graphic parts. The text part contains data on a major construction object, description of the technical and other solutions made, explanations, references to the regulating and (or) technical documents used for preparation of the design documentation and the results of calculations, supporting such solutions. The graphic part depicts the technical and other solutions made, and is presented in a graphic form as drawings, schemes, layouts and other documents.

As it is expressly specified that the design documentation contains description (in the form of the text and graphic information) of engineering proposals, such documentation is the technical one which complies with the Civil Code provisions regarding conclusion of a contract of hiring work under the technical documentation.

Similarly the scientific and design documentation, developed under the restoration rules and regulations to be mandatorily applied, should be published when placing restoration works orders [8].

This opinion is also shared by the Federal Antimonopoly Service - it informs in its letter dated July 23, 2010 [9], that the design estimate documentation must constitute a part of the bidding documents and is to be posted in full on an official web-site.

The existing procedure for placing orders in the field of the construction and assembly and repair and restoration works prevents from bidding only for the amount of works, without determining a specific list of works. This provided for a significant factor in counteracting corruption - up to 2005 there was a widely used practice when in the course of the contract performance there were changes occurred in the price and the list of works ordered due to the changes introduced to the project.

Publication of the design documentation (in case of restoration works - science and design documentation) significantly increases the designers' responsibility doe such documentation development. Now all design concepts affecting the scope and cost of works are subject to immediate determination. Non-change of the contract for construction in the course of performance thereof (that is no change of the price and/ or the scope of the works done) requires the customer to take a balanced decision as to the acceptance of the documents from the design organization (recognition of the project to be of high quality and in full compliance with the customer's requirements and with the regulatory documents). And this is fully in line with the state interests and focused on protection thereof.

Thus, Federal Law "On placement of orders to supply goods, carry out works and render services for meeting state and municipal needs" has ensured publicity in the state order placing and by this has materially influenced the customers' responsibility for the projects under bidding as well as the development of competition. At the same time the issue related to organizing placement of the construction orders (insofar as it concerns the contractor selection procedure) needs to be defined more specifically which is to be taken into account when developing the state order legislation.

\section{REFERENCES:}

1. Civil Code of the Russian Federation. Part II (revision dated 30.11.2011). Federal Law of January 26, 1996 No.14-FZ. // Collection of legislation of the Russian Federation. 1996. No.5, Article 410. English version available at: http:// www.russian-civil-code.com/PartII / SectionIV/ Subsection1/Chapter37.html. Accessed: November 15, 2012.

2. On placement of orders for supplies of goods, performance of works, provision of services for state and municipal needs (revision dated 23.07.2012). Federal Act of J uly 21, 2005 No. 94-FZ. // Collection of legislation of the Russian Federation. 1995. No.30 (part 1), Article 3105. English version available at: http:// en.fas.gov.ru/legislation/legislation_50484.html. Accessed: November 15, 2012.

3. Asaul A. N., Koshcheev V. A. State business in construction (state construction order) // Modern high technologies. 2010. No.2. p.140. Available at: URL: http://elibrary.ru/item.asp?id =13042911 Accessed: November 15, 2012.

4. Oparin S. G., Sulima V. V. Development of tenders for the right to conclude a state contract for construction of transport infrastructure facilities // Scientific and technical journal of Saint 
Petersburg State Polytechnical University. 2011. No125. p.55-62. Available at: URL: http:// elibrary.ru/ item.asp?id=16926952 Accessed: November 15, 2012.

5. Regulation on the structure of the sections of design documentation and requirements to their contents: approved by the statement of the Government of the Russian Federation dated February 16, 2008, No. 87 // Collection of legislation of the Russian Federation. 2008. No.8.

6. Polovtsev I.N. On the scope of documentation to be published for performance of order placement procedures in the field of construction in the Russian Federation // Modern scientific research and their practical application, edited by Alexandr G. Shibaev, Sergiy V. Kuprienko, Alexandra D. Fedorova. Vol. J21213 (Kupriyenko Sergiy Vasilyovich, Odessa, 2012) Article CID Number J 21213-022. Available at: http://sworld.com.ua/index.php/ru/e-journal/the-content-ofjournal/j212/ 13766-j21213. Accessed: November 15, 2012.

7. Letter by the Deputy Minister of Culture of the Russian Federation, K.G.Cherepennikov, dated January 11, 2012, No. 3-01-39/10-KCH. Access from the legal reference system of ConsultantPlus (Accessed: November 15, 2012). Available at: http://www.mkrf.ru/ documentations / letter/ detail.php?ID=213102. Accessed: November 15, 2012.

8. Polovtsev I. N. Russian rules of restoration. Obligatory or recommendatory document? // European researcher. 2012. Vol. 27. No 8-2. p.1269-1271. Available at: http://www.erjournal. ru/journals n/ 1345308675.pdf. Accessed: November 15, 2012.

9. Letter by the Federal Antimonopoly Service dated July 23, 2010. No. IA/23610. The document was not published. Access from the legal reference system of ConsultantPlus (Accessed: November 15, 2012). Available at: http:// eao.fas.gov.ru/sites/ eao.f.isfb.ru/files/analytic/ 2012/01/27/ tekst_pisma_no_ia23610_ot_23.07.2010g..pdf. Accessed: November 15, 2012.

УДК $72+338$

\title{
Публикация технической документации необходимой для государственного строительного заказа
}

\author{
Игорь Николаевич Половцев
}

Санкт-Петербургский государственный университет, Россия

Университетская наб. д.7/9, Санкт-Петербург, 199034

Заместитель начальника управления капитального строительства и реконструкции

E-mail: i.polovtsev@spbu.ru

Аннотация. Статья посвящена вопросу публикации технических документов, необходимых для размещения государственных и муниципальных строительных заказов (подрядов). Автор приходит к выводу, что публикация технических документов способствует развитию конкуренции в области строительства. Кроме того публикация технической документации способствует увеличению ответственности архитекторов и конструкторов за качество проектных работ, а также заказчиков при оценке выполненных на заказ проектов.

Ключевые слова: строительный подряд; реставрация; государственный заказ; проектная документация; строительный проект; конкуренция. 